\title{
A biztonság és a biztonságmenedzsment vizsgálata vállalati nézőpontból
}

\section{Inspection of Security and Security Management from a Company Point of View}

Mi a biztonság, mit értünk alatta, amikor szóba hozzuk, megfogalmazzuk? Mit értünk ma Magyarországon vállalati biztonságmenedzsment alatt, valamint milyen fejlettségi szintre pozícionálhatjuk napjainkban a nemzetközi biztonságmenedzsment jelenlegi vezető tudományos, szakmai iránymutatásaihoz viszonyítva?

A hazai szakirodalomban többféle, többrétegű és a biztonságot különbözőképpen értelmező meghatározásokkal találkozhatunk, ezek összefoglalása nem célja az értekezésnek, sokkal inkább annak az iránynak a felvázolása, ami a legközelebb áll a vállalati biztonságmenedzsmenthez.

A biztonság megszervezéséröl született szakvélemények, akár egy objektum esetében, akár egy rendszer felépítéséröl értekeznek, a vagyonvédelmet egy piramisformával ábrázolják. Ezt a piramist általában három részre osztják fel, mechanikai, elektronikus és élőerős védelemre.

Ezzel szemben én egy átfogóbb, komplex megközelítést javaslok, ami véleményem szerint jobban lefedi a biztonsági rendszert. Kiemelem a biztonságmenedzsment elengedhetetlen és vezető szerepét. A biztonságmenedzsment a biztonsági rendszer vezetö része/eleme, amely megtervezi, létrehozza, müködteti és folyamatosan tökéletesíti a teljes biztonsági vagy védelmi rendszert, ami nélkül nem beszélhetünk megfelelő, hatékony védelemről.

Kulcsszavak: biztonság, biztonságmenedzsment, védelem, mechanikai, elektronikus, élőerős, komplex biztonságmenedzsment

What is security, what does it mean when we talk about it and formulate it? What do we mean by corporate security management in Hungary today, and what level of development can we position today in relation to the current leading scientific and professional guidelines of international security management?

Flex, biztonsági főigazgató, Európa, Közel-Kelet, Afrika, e-mail: zszolyomi1@gmail.com, ORCID: https://orcid. org/0000-0002-2800-1430 
In the Hungarian security literature we can find several, multi-layered and differently interpreted definitions, the summary of which is not the aim of the article, but rather to establish the direction that is closest to corporate security management. Experts on the setup of security system, either in the case of a single object or in the design of a system, depict security system as a pyramid. This pyramid is usually divided into three parts, mechanical, electronic and human guarding forces. In contrast, I suggest a more comprehensive, complex approach, which in my opinion covers the security system more completely. I highlight the essential leading role of security management. Security management is the leading component of a security system that designs, creates, operates and continually improves a complete security or defence system, without which we cannot talk about adequate, effective protection.

Keywords: security, security management, protection, mechanical, electronic, human guarding, complex security management

\section{A biztonság és annak értelmezése}

Mi a biztonság, mit értünk alatta, amikor szóba hozzuk, megfogalmazzuk? A mai angol nyelvhasználatban a "security" a latin "securitas” (biztonság, gondtalanság, lelki nyugalom) [1] szó többlépcsős módosulásával került be. Ez az átvétel és átalakulás az 1100-as évek elejétől az 1400-as évek végéig tartott (Sikernesse, Sikerhede, Sikerte, majd Security) [2]. A magyar nyelvben a biztonság szó „biztonlét” jelentéssel került be az 1862-ben kiadott Czuczor Gergely féle szótárba [3], ahol még új szóként jelölik: „Divatba nem régen jött szó, a régi és helyesebb biztosság értelmében" [3: 680.]. A jelenleg is használatos magyar értelmező szótár szerint a biztonság jelentése a következő: „A dolgoknak, életviszonyoknak olyan rendje, olyan állapot, amelyben kellemetlen meglepetésnek, zavarnak, veszélynek nincs v. alig van lehetösége, amelyben ilyentől nem kell félni"[4].

A hazai szakirodalomban többféle, többrétegű és a biztonságot különbözőképpen értelmező meghatározásokkal találkozhatunk, ezek összefoglalása nem célja az értekezésnek, sokkal inkább annak az iránynak a felvázolása, ami a legközelebb áll a biztonságmenedzsmenthez.

Számomra a legjellemzőbb módon határozza meg a biztonság fogalmát: Dr. Berek Lajos, Dr. Berek Tamás és Berek László 2016-ban az Óbudai Egyetemen megjelent, Személy és vagyonbiztonság című kiadványa, amelynek az első fejezetében foglalkoznak a szerzők a biztonság fogalmának értelmezésével.

„A biztonság személyek és szervezetek azon állapota, melyet, a létüket, illetve rendeltetésszerü müködésüket veszélyeztető szándékos jogellenes magatartások és az azokkal szemben alkalmazott védelmi erőforrások együtthatása határoz meg"[5: 6.].

Ezzel a megfogalmazással tudok a leginkább egyetérteni, hiszen, ha nagyon leegyszerüsítjük a biztonság értelmezését, akkor az veszélymentességet, a veszély, vagy a fenyegetettség hiányát jelenti, amit tökéletesen lefed a fenti definíció. Még a biztonság alapértelmezésén kívül szükségesnek tartom megemlíteni a biztonság fontosságát. A biztonságot Maslow piramisa [6] alapvető fontosságúnak tartja, mindjárt a második szinten említi a létszükségletek kielégítése után, vagyis a biztonságra 
igény van, a biztonság az ember alapvető szükséglete. (Szükséglet: a bennünk támadt hiányérzet megnyilvánulása [saját megfogalmazás].)

Összefoglalhatjuk, hogy a biztonság olyan személy vagy szervezet állapota, amelynek léte és rendeltetése van. Ezt a létet, illetve rendeltetést veszélyeztetheti valami, amely veszély kivédésére és elhárítására az ember létrehozza, elkészíti a védelmet. Például a személy vagy szervezet értékeit, vagyonát veszélyeztetheti több tényező is, tűz, természeti vagy ember által okozott katasztrófa, támadás, lopás stb. A lopás példájánál maradva ezt a veszélyeztetést vagy más szóval kockázati tényezőt az ember úgy tudja elhárítani, ha védelmi berendezéseket telepít, őrséget szervez és müködtet, kapcsolatban van a bünüldöző hatóságokkal.

A fentiekböl jól nyomon követhető, hogy értekezésemben nem a nagy egészszel, a mindenre kiterjedő általános biztonsági kérdésekkel, hanem annak egy szeletével, a multinacionális és/vagy nagyvállalatok, gazdálkodó szervezetek biztonságával kívánok foglalkozni.

„A biztonságot közvetlenül két tényező határozza meg. Az egyik a veszélyeztetés, azaz a szándékos jogellenes magatartások, melyek negatívan befolyásolják a biztonságot. A másik az alkalmazott védelmi erőforrások mennyisége és minősége. Minél több erőt és hatékonyabb őrzést és védelmet alkalmazunk, annál magasabb szintü lesz a biztonság. Ugyanis az alkalmazott védelmi erőforrások a szándékos jogellenes magatartásokkal szemben hatnak, azt akadályozzák, a legjobb esetben megakadályozzák" [6].

A biztonság megszervezéséröl született szakvélemények, akár egy objektum esetében, akár egy rendszer felépítéséről értekeznek, a vagyonvédelmet egy piramisformával ábrázolják. Ezt a piramist általában három részre osztják fel, mechanikai, elektronikus és élőerős védelemre.

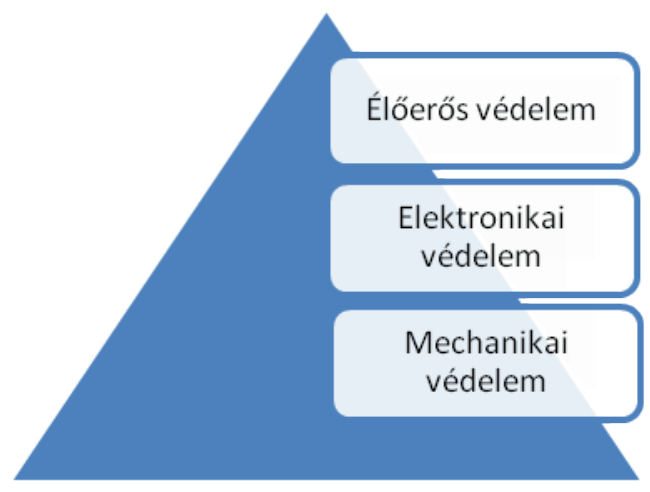

1. ábra

A vagyonvédelem [a szerző szerkesztése]

Ennek a háromszintű piramisnak a kibővített formáját használják sokan, hivatkozva Utassy Sándor Komplex villamos rendszerek biztonságtechnikai kérdései címü doktori (PhD) értekezésére. Ebben a piramisban már megjelennek védelmi intézkedések, biztosítás és a kockázat is, de a biztonságmenedzsmentet senki sem említi [7]. 


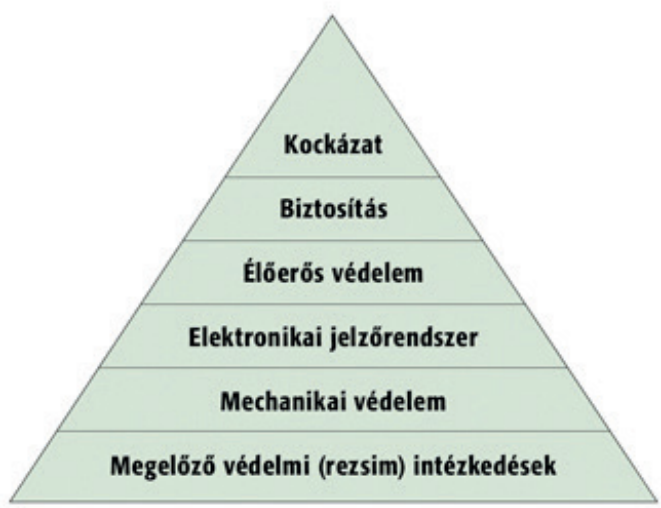

2. ábra

Utassy-féle vagyonvédelem [17]

A kérdést az „integrált fizikai védelem" kialakítása szemszögéből megközelítő szemlélet [8] a komplex vagyonvédelem egymáshoz kapcsolódó összetevőiként azonosítja a mechanikai, az elektronikai, valamint az élőerős védelmet, amelyek együttese kiegészítve a megelőző intézkedésekkel csökkenti a kockázatok előfordulási valószínűségét és a bekövetkező események káros hatását [8].

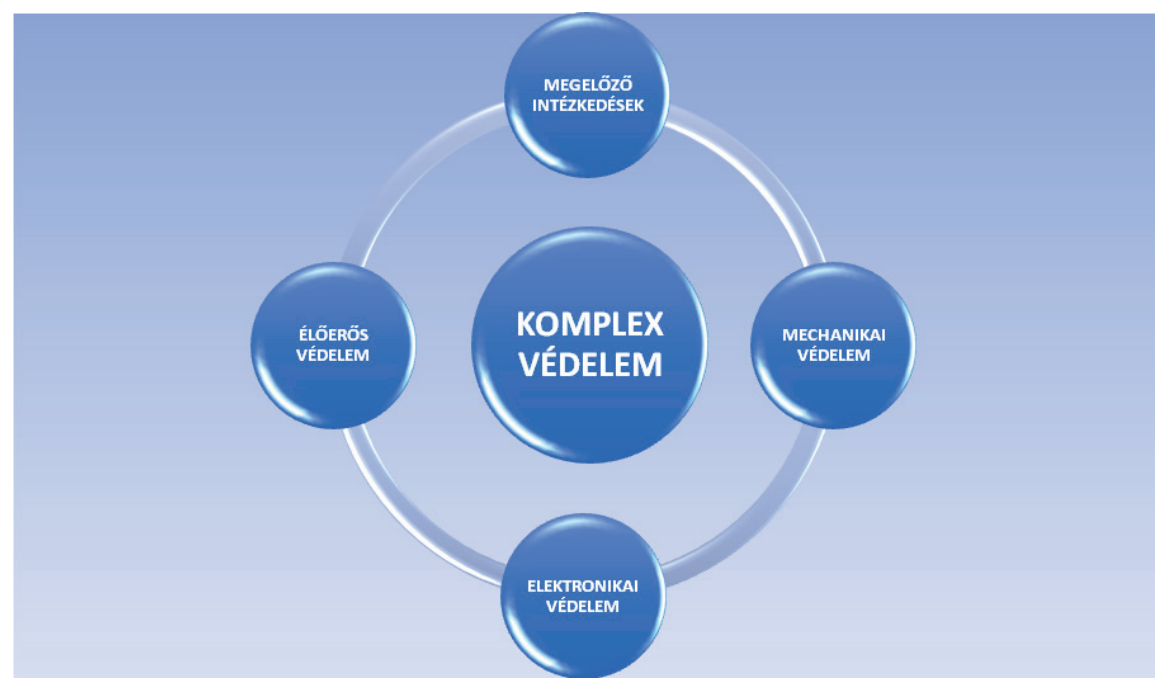

3. ábra

A komplex vagyonvédelem föbb komponensei [8]

A fenti csoportosítás komponenseit egyenként vagy akár egyszerre is alkalmazhatják, azonban a magas szintü biztonság a fentiek összehangolt, optimális, arányos alkalmazásával érhető el, ez a komplex őrzés-védelem [9]. 
Az őrzés és védelem komplexitását vizsgáló szakemberek szerint ez az egyik meghatározó problémája a vagyonvédelemnek, ugyanis kapcsolatukat az alapján lehet vizsgálni, hogy melyik milyen mértékben járul hozzá a biztonsághoz, amit nehéz megállapítani [5].

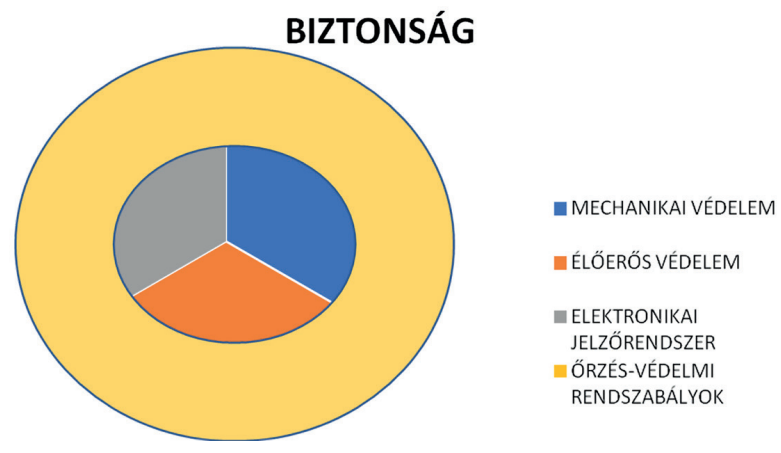

4. ábra

A védelmi erőforrások és az alkalmazott rendszabályok kapcsolata [9]

Ezek arányának kialakítását gondos tervezőmunka kell hogy megalapozza. A már üzemelő objektumok területén végzett átalakítások, kivitelezések azonban kihívások elé állítják a biztonsági szervezeteket, mivel kényszerüen változtatni szükséges a már kialakított arányokon. A kivitelezési munkák dinamikusan változó környezetet generálnak, a biztonsági kockázatok kezelésére a tervezői szakaszban kell felkészülni. Az alaprendeltetésének megfelelően a gazdasági társaság biztonsági szervezetének feladata, hogy müködésével támogassa a szóban forgó társaság gazdasági érdekeinek megvalósulását [10].

Olyan speciális eset is előfordulhat, amikor a komplex védelmi rendszer üzemeltetését biztosító villamos hálózat hiánya korlátozza például az elektronikai alrendszer megfelelő arányának kialakítását [11].

A fentiek fényében egy gazdasági társaság biztonsági szervezetének szemszögéből vizsgálva a kérdést, én egy átfogóbb megközelítést javaslok, ami véleményem szerint jobban lefedi a biztonsági rendszert. A lenti grafikus ábrázolás (5. ábra) alapján látható, hogy a három fö elem a mechanikai, elektronikus és élőerős védelem van a centrumban, ahol azonos arányban szerepelnek, hiszen minden egyes szervezet/ vállalat esetében annak sajátosságai, szükségletei alapján határozzák meg az arányait. Például egy hulladékgyűjtő állomás elektronikai védelmi rendszere nem hasonlítható egy IT-vállalat szerverfarmjának elektronikai védelmi rendszeréhez, vagy egy multinacionális óriásvállalat beléptető-rendszere sem említhető együtt egy körülbelül tízszemélyes iroda beléptetési rendszerével. Mindezekre a fő védelmi elemekre hatnak a kockázati tényezők, amelyeket számításba kell venni, ezek előzetes elemzésének eredményei alapján szükséges kialakítani a fő védelmi rendszereket. Ezt az egész rendszert pedig körbefonja a biztonságmenedzsment. A biztonságmenedzsment a biztonsági rendszer vezető része/eleme, amely megtervezi, létrehozza, müködteti, 
és folyamatosan tökéletesíti a teljes biztonsági vagy védelmi rendszert, ami nélkül nem beszélhetünk megfelelő, hatékony védelemről.

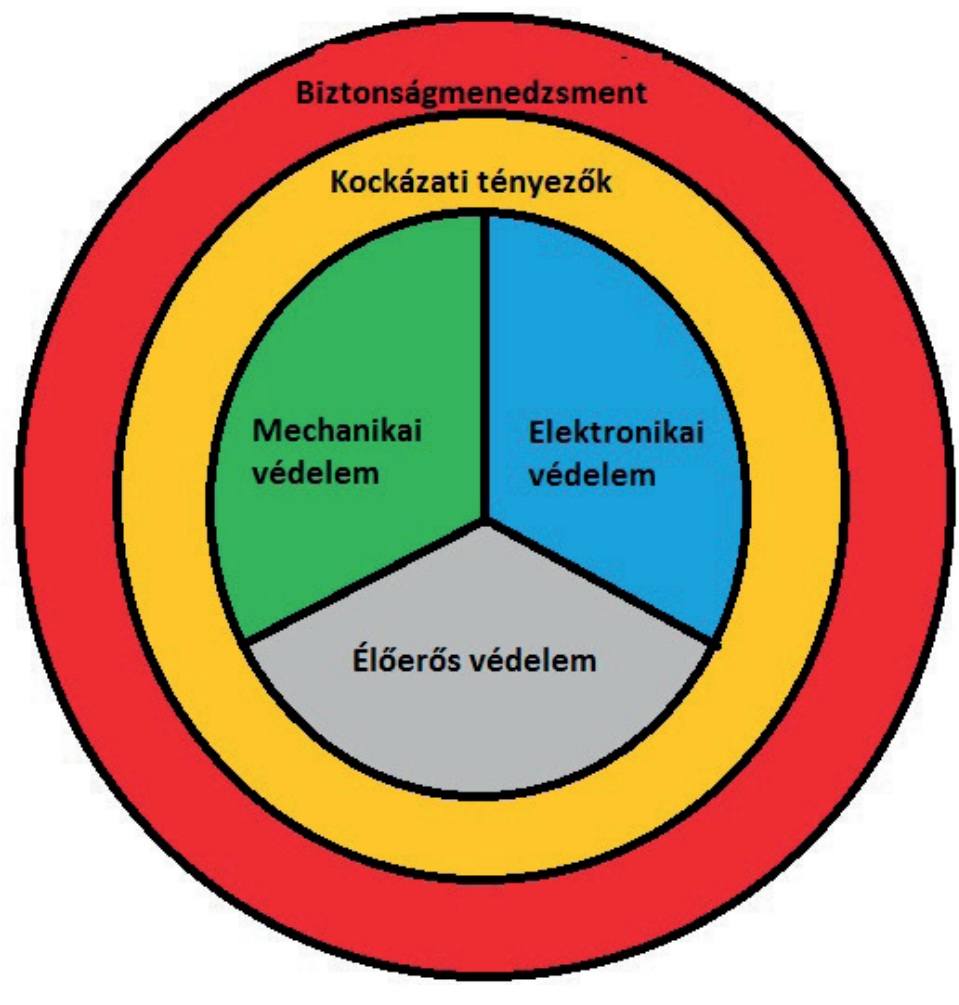

5. ábra

A biztonsági rendszer [a szerző szerkesztése]

A biztonságot befolyásolják közvetlen és közvetett tényezők, a közvetett tényezők, mint a jogi környezet, biztosítási intézményrendszer, gazdasági tényezők, közbiztonság, munkanélküliség stb. [5: 6.]. A közvetlen tényezőkről már volt szó, ezek a kockázati tényezők és a védelmi erőforrások [5: 6.]. Ebbe én még beleértem a biztonságmenedzsmentet is, mert a biztonságmenedzsment a lehető legközvetlenebbül befolyásolja a biztonságot mint védelmi erőforrás. Egy szint felett, ami lehet árbevétel vagy dolgozói létszám, vagy a termék vagy tevékenység értékessége, bizalmassága, egyértelműen kötelezően kellene biztonságmenedzsmentet alkalmazni a biztonsági rendszer kialakítására és múködtetésére. Sajnálatos módon elterjedt az a nézet, hogy a biztonság egy improduktív szervezet, mert nem hoz létre bevételt. Ezt az álláspontot a felkészületlen vezetők vallják, akik nem képesek átfogó rendszerekben gondolkozni, ezért ezek a vezetők és az általuk vezetett szervezet/vállalat hosszú távon nem lehet sikeres, mert nem tudják a rájuk bízott szervezetet a leghatékonyabban működtetni. Ez a hozzáállás helytelen. A biztonsági szervezet egy felkészült és hatékony biztonságmenedzsmenttel a szervezet/vállalat veszteségeinek minimalizálásával 
vagy megszüntetésével jelentős financiális bevételt tud teremteni (nem engedi, hogy a dolgozók, illetve külsősök ellopják a vállalat értékeit). Egy lehetséges másik útja a biztonságmenedzsment vállalati értékteremtésének, amikor bevonják a leltárhiányok feltárásába, illetve azok megszüntetése érdekében bevezetendő leltárfolyamatok megtervezésébe, ellenőrzési pontok kialakításába.

Összefoglalva megállapíthatjuk, hogy egy felkészült biztonságmenedzsment a szervezet bevételeit növelheti, hatékony tevékenységével produktív ágazatként növelheti a vállalat pénzügyi hatékonyságát.

\section{A biztonságmenedzsment}

Mit értünk ma Magyarországon vállalati biztonságmenedzsment alatt, valamint milyen fejlettségi szintre pozícionálhatjuk napjainkban a nemzetközi biztonságmenedzsment jelenlegi vezető tudományos, szakmai iránymutatásaihoz viszonyítva?

A vállalati biztonságmenedzsment hazai kialakulásának előzményei, gyökerei, lényegének értelmezése, jelenlegi szintjének a gyakorlatban megvalósuló irányai különböző mértékben eltérnek a nemzetközi vezető eljárásmódoktól, vagy nem teljes egészében fedik le a vállalati biztonságmenedzsment teljes spektrumát, ezért szükséges és kívánatos az átfogó komplex biztonságmenedzsment-eljárás mielőbbi általános gyakorlattá válása.

A rendszerváltás vagy rendszerváltozásig hazánkban nem létezett vállalati biztonságmenedzsment. Az akkori társadalmi és gazdasági rendszer vagyon-, és személybiztonsági kérdésekben kizárólag az állami rendészeti, tűz-, katasztrófa-, polgárvédelmi (és titkosszolgálati) szervekre támaszkodott. Ezen kívül, helyenként, főleg veszélyes ipari üzemekben létrehozott üzembiztonsági rendészet tevékenykedett, amely inkább munkabiztonsági feladatokat látott el, de foglalkozott vagyonvédelemmel is. Még megemlíthetjük a különböző őröket a rendszerváltozás előtti időszakból, mint akik szintén a biztonsággal foglalkoztak a 20. század nagyobbik részében Magyarországon, például éjjeliőr, vadőr, mezőőr, halőr stb. Az állami és a társadalmi tulajdon kollektív tulajdon volt, egyéni értelemben csak személyi tulajdonról beszélhettünk. Ebben a korszakban magántulajdon gyakorlatilag nem létezett, az össztulajdon 2\%-át sem érte el, így annak védelmével sem kellett foglalkozni.

Ilyen biztonsági háttér mellett ért el minket a szabad piacgazdaság minden biztonsági kockázati tényezőjével együtt. Erre nem voltunk felkészülve, mint ahogy az elbizonytalanított rendészeti szervek sem. Az alapfeladatuk ellátására igyekeztek erőiket átcsoportosítani, miközben régebbi szerepükhöz képest kivonultak a gazdasági területről. Ekkor szembesültek az immár tulajdonossá vált vezetők is azzal, hogy már maguknak kell gondoskodniuk az értékeik védelméről. Mivel vállalatibiztonságmenedzsment-képzés egyáltalán nem létezett, illetve még ma sem nagyon létezik, ezért különböző vezetési irányok alakultak ki, amelyek még ma is tartják magukat, bár már a kívánatos komplex biztonságmenedzsment is kialakulóban van. 
Biztonságmenedzsment szemléleti irányai:

- rendöri-katonai,

- őrzésvédelmi,

- munkavédelmi,

- biztonságtechnikai,

- informatikusi,

- komplex biztonságmenedzsment.

A rendőri-katonai irány: volt rendőri és katonai vezetők által bevezetett irányzat, amely az objektumok fizikai védelmére, illetve a nyomozásokra koncentrál. Ez a legdominánsabb biztonságvédelmi irányzat jelenleg hazánkban.

Az őrzésvédelmi irány: vagyonvédelmi szolgáltatók szemléletéből alakult ki, fő súlypont az emberi (őrök általi) őrzésre helyeződik, általában „külsős” szemszögből ítélik meg a szükséges védelmi szintet.

A munkavédelmi irány: (safety) munkavédelmi mérnökök által képviselt elgondolás, ahol a munka-, tűz- és egészségvédelemre helyeződik a fókusz. A vészhelyzetmenedzsmenten belül a vészhelyzeti reagáláson van a fő hangsúly.

A biztonságtechnikai irány: biztonságtechnikai mérnökök általi megközelítés, ami a biztonságtechnikai rendszeren és elemein alapul, mint a kamerarendszer, beléptetörendszer vagy riasztórendszerek.

Az informatikusi irány: informatikus mérnökök által gyakorolt eljárásrend, jellemzője az informatikus, analitikus rendszerszemlélet, amelyben majdnem kizárólagos prioritása a számítástechnikai rendszernek, elemeinek, illetve a hálózatvédelmi rendszereknek van.

Mind az öt előzőleg felsorolt biztonságmenedzsment-irányzat a lehető legszükebben értelmezi a biztonságmenedzsmentet, kizárólag a saját szakmai elméletének és gyakorlatának megvalósítását tartja feladatának, a biztonságmenedzsment egyéb feladatait igyekszik kizárni a felelősségi területéből, illetve áthárítani más szervezeti egységekre, lemondva ezáltal az átfogó szintű kontroll kialakításáról.

Példaképpen a rendőri-katonai, illetve az őrzésvédelmi irányzat számára megfelelő megoldás az, ha nem kell részt venniük az információbiztonság megvalósításában (e-mail-ellenőrzés, internethasználat-figyelés, vállalat kárára történő információáramlás stb.), azt teljes mértékben ráhagyják az IT-szervezetre. Ez egy kényelmes felállási mód véleményük szerint, de ezzel át is adják a teljes ellenőrzést az IT-szervezetnek a terület felett, vagyis a szükséges adatok nem állnak azonnal a rendelkezésükre majd egy jövőbeni visszaélés kivizsgálásához, vagy ezekhez az adatokhoz csak körülményesen és késedelemmel juthatnak hozzá [12].

Egy középkori latin szólást szeretnék idézni, ami úgy szól, hogy: „Extra Hungariam non est vita, si est vita, non est ita." Ami magyarul így szól: Magyarországon kívül nincs élet, ha van élet, nem ilyen [13]. Ezt én úgy értelmezem, hogy minden általános szabályt valamilyen mértékben az adott hely/ország szokásai szerint módosítani kell, vagyis a helyi sajátosságokat figyelembe kell venni, hogy a szabály megfelelően tudjon megvalósulni.

A komplex biztonságmenedzsment: (security) nemzetközi, elsősorban angolszász alapú megközelítés, betelepült multinacionális vállalatok által hozott szigorú biztonsági 
kultúra és eljárásrend. A magántulajdon védelme megkövetelte és kialakította saját védelmi rendszerét, ami a 20 . század utolsó harmadában indult lendületes fejlődésnek. Jellemzője, hogy átfogó módon áll a biztonsághoz, annak minden elemét igyekszik integrálni a rendszerébe [12].

Szakirodalmunk szempontjából szintén megfigyelhetjük ugyanezt a tagozódást. Legszélesebb a paletta a biztonságtechnikával foglalkozó kiadványok tekintetében, nevükből kifolyólag ezekre a müvekre alapvetően jellemző az egyes témák részletes, mélységekbe menő mérnöki feldolgozása, sem itt, sem a többi területen nem találunk átfogó, komplex szemléletű tanulmányt, ami a biztonságmenedzsmentről szólna. Komplexitásra való törekvés nézőpontjából mindenképpen meg kell említeni az 1999-ben megjelent Hivatása a védelem [14] címü kiemelkedő munkát, amely 14 író és négy szerkesztő közös munkájának eredménye. Ebben a müben a szerzők sorra veszik az objektumvédelem, személyvédelem, kivonuló szolgálat, rendezvénybiztosítás, pénz- és értékszállítás kérdéseit, őrök által használt technikai eszközöket stb. Szemléletére jellemző a komplexitásra való törekvés, de érezhető a végrehajtói vagy szolgáltatói nézőpont. Főleg az őrzésvédelmi szemlélet tapasztalható benne némi rendőri-katonai befolyással. Kitűnő példa az informatikai megközelítésre Vasvári György Vállalati biztonságirányítás [15] címü munkája, amelynek az alcíméből már láthatjuk is, hogy az „Informatikai biztonságmenedzsment"-ről szól. Szövényi György Biztonságszervezői menedzsment [16] címü értekezésében még többségében megtalálható a rendőri-katonai szemlélet, nagyon erős jogi háttérrel, de már a komplex biztonságmenedzsment is megnyilvánul egyes elemeiben. Ilyen például az A biztonságszervezö menedzser eszköztára (84-93. oldal), ahol a humán biztonság nélkülözhetetlen elemeit fejti ki a szerző. Szintén figyelemreméltó, hogy a szerző már használja A komplex biztonságvédelmi rendszer kialakítása (98-107. oldal) címü fejezetében a komplex kifejezést, de még nem érti alatta az átfogó komplex biztonságmenedzsmentet teljes egészében. Sajnos a témánkat teljes mértékben lefedő, magyar, összefoglaló mü még nem készült el, ezt pótolni kell.

Nem szabad elfeledkezni arról, hogy jelentős számban jelennek meg hazai publikációk a biztonsággal foglalkozó lapokban, mint a Detektor Plusz magazin, az Árgus, vagy a Biztonság. Több hazai egyesület, például a Magyarországi Biztonsági Vezetők Egyesülete, a Magyar Biztonsági Fórum (MBVE, MBF) vagy a Személy-, Vagyonvédelmi és Magánnyomozói Szakmai Kamara igen aktívan tevékenykedik annak érdekében, hogy a biztonság a megfelelő szintre kerüljön. Még sok a teendő ebben az irányban, hogy amikor a biztonságmenedzsmentről beszélünk, akkor ugyanazt is értsük alatta mindannyian. Ezt akkor érhetjük el, ha van megfelelő oktatás, tananyag és rendszer. Ennek a célnak az eléréséért mi, a jelenkori biztonsági szakemberek vagyunk a felelősök, nekünk kell tenni azért, hogy mindez megvalósulhasson.

\section{Összefoglalás}

A hazai viszonyokat közelebbről érezzük, de ha kitekintünk Európába, vagy még távolabb a világ bármelyik régiójába, akkor sem éppen megnyugtató érzéseink keletkeznek. Számos problémát, krízishelyzetet, érdekellentétet, konfliktust tapasztalhatunk. 
Elegendő azonban a közelmúltbeli 2008-as gazdasági válságra, a 2011-gyel kezdődött „arab tavaszra," a mostanában is pengeélen táncoló, európai uniós adósságválság megoldásának kísérleteire, a migrációs nyomásra és a globális felmelegedés hatásaira, a világ népességének növekedési ütemére, valamint az atomhatalmak szemben álló politikai és gazdasági érdekeire gondolni. Ezek a tendenciák mind azt mutatják, hogy pillanatok alatt romolhat az általános biztonság, több lesz az anyagi javak elleni támadás, lopás, betörés, szállítmányok eltulajdonítása, fosztogatása. Vagyis jóval több feladatunk lesz és sokkal mostohább körülmények között kell mindezeket elvégeznünk. Mindezekre fel kell készülnünk, mert csak akkor leszünk képesek megvédeni a ránk bízott értékeket, ha egy hatékonyan müködő, a biztonság teljes spektrumát átfogó, komplex biztonsági rendszert tudunk müködtetni. A szerencsésebbeknek közülünk ehhez rendelkezésére is fognak állni a szükséges anyagi alapok, a kevésbé szerencséseknek, pedig még sokkal hatékonyabban kell majd felhasználniuk szellemi kapacitásaikat.

Összegezve megállapítható, hogy a rendszerváltozástól eltelt majdnem három évtized alatt a hazai biztonságmenedzsment több irányban is jelentős eredményeket tud felmutatni, határozott fejlődésen ment keresztül, de az összefogó, rendszerező, standardizáló feladatok még előttünk vannak. Kívánatossá vált egy egységes, komplex biztonságmenedzsment-rendszer kialakítása, amely a nemzetközi eljárások mentén a hazai viszonyok figyelembevételével képes átfogó, hatékony, jól működő rendszerként üzemelni.

\section{Hivatkozások}

[1] Dictzone, Latin-magyar szótár, „securitas,” Dictzone, [Online]. Elérhető: https:// dictzone.com/latin-magyar-szotar/securitas (Letöltve: 2019. 09. 01.)

[2] Online Etymology Dictionary, "security," Online Etimology Dictionary, [Online]. Elérhető: www.etymonline.com/word/security (Letöltve: 2019. 09. 01.)

[3] G. Czucor, A Magyar Nyelv Szótára I. Pest: Emich Gusztáv, 1862, [Online]. Elérhetö: https://mek.oszk.hu/cgi-bin9/czuczor2.cgi?kezdobetu=B\&szo=BIZTONS\%C3\%81G\&offset=108 (Letöltve: 2019. 09. 01.)

[4] Arcanum, A magyar nyelv értelmező szótára, „biztonság,” Arcanum, [Online]. Elérhetö: www.arcanum.hu/hu/online-kiadvanyok/Lexikonok-a-magyar-nyelvertelmezo-szotara-1BE8B/b-1EF8E/biztonsag-2119D/ (Letöltve: 2019. 09. 01.)

[5] L. Berek, T. Berek és L. Berek, Személy-és vagyonbiztonság. ÓE-BGK 3071, Budapest: Óbudai Egyetem, 2016., p. 6.

[6] K. Papp és A. Ujváriné Siket, Az egészségügy és az ápolás általános alapelvei. Debreceni Egyetem Egészségügyi Kar, 2014., p. 5. Az alapvető emberi szükségletek és kielégítésük, 19. kép, Maslow szükségleti piramisa, [Online]. Elérhető: www. tankonyvtar.hu/hu/tartalom/tamop412A/2010_0020_apolas_magyar/5_az_alapvet_emberi_szksgletek_s_kielgtsk.html (Letöltve: 2019. 09. 01.)

[7] S. Utassy, „Komplex villamos rendszerek biztonságtechnikai kérdései,” Doktori (PhD) értekezés, 2009, [Online]. Elérhető: https://adoc.tips/komplex-villamosrendszerek-biztonsagtechnikai-kerdesei.html (Letöltve: 2019. 09. 01.) 
[8] T. Berek, „Vészhelyzeti víztermelő létesítmények integrált fizikai védelme," Müszaki Katonai Közlöny, 27. évf. 4. sz., pp. 227-236., 2017.

[9] L. Berek és A. Vass, „Gázturbinás erőműi objektum védelme,” Hadmérnök, 9. évf. 2. sz., pp. 5-15., 2014.

[10] T. Berek és T. Horváth, „Fizikai védelmi rendszerek dinamikusan változó környezetben," Hadmérnök, 9. évf. 2. sz., pp. 16-24., 2014.

[11] A. Vass és L. Berek, „Napenergia és az elektronikai jelzőrendszer, villamos energia hálózattól távol lévő objektumok védelmének lehetőségei," Hadmérnök, 10. évf. 2. sz., pp. 41-57., 2015.

[12] Zs. Zólyomi, „Biztonságmenedzsment itthon, napjainkban,” Detektor Plusz, 5. sz., pp. 14-15., 2011.

[13] Idegen szavak szótára, „Extra hungariam non est vita, si est vita, non est ita,” Idegen szavak szótára, [Online]. Elérhető: http://idegen-szavak-szotara.hu/extra-hungariam-non-est-vita,-si-est-vita,-non-est-ita.-jelent\%C3\%A9se (Letöltve: 2017. 11. 19.)

[14] J. Devecsai, J. Nán, M. Varga és L. Gábor, Hivatása a védelem. Budapest: CEDIT Kft., 1999.

[15] Gy. Vasvári, Vállalati biztonságirányítás. Kiskunlacháza: Time-Clock Kft., 2007.

[16] Gy. Szövényi, Biztonságvédelmi kézikönyv. Budapest: KJK-Kerszöv, 2000.

[17] A. D. Kovács, „Objektumvédelem,” Detektor Plusz, 4. sz., 2018. [Online]. Elérhetö: http://detektorplusz.hu/index.php?m=23998 (Letöltve: 2019. 09. 01.) 